ISSN 1392-3196 / e-ISSN 2335-8947

Zemdirbyste-Agriculture, vol. 105, No. 2 (2018), p. 123-132

DOI 10.13080/z-a.2018.105.016

\title{
Nano titanium dioxide and nitric oxide alleviate salt induced changes in seedling growth, physiological and photosynthesis attributes of barley
}

\author{
Afshin KARAMI, Ali SEPEHRI \\ Bu-Ali Sina University \\ Hamedan, Iran \\ E-mail: a_sepehri@basu.ac.ir
}

\begin{abstract}
There has been increasing interest in the use of engineered nanoparticles in agricultural science. Recent research has revealed that nanoparticles have both negative and positive impacts on plant growth performance. The present study is motivated by conflicting results from previous researches on the probable impact of engineered nanoparticles on crop growth. Hence, a greenhouse experiment was conducted to investigate the possible impacts of nano titanium dioxide (n-TiO ) $\left(500,1000\right.$ and $\left.2000 \mathrm{mg} \mathrm{kg}^{-1}\right)$ and nitric oxide (NO) $(100 \mu \mathrm{M} \mathrm{SNP}$ as NO donor) on growth, physiological and photosynthetic parameters of barley seedlings (at the $30^{\text {th }}$ stage of Zadoks growth scale) under salinity stress. Salt-stressed plants showed stunted growth, decreased shoot and root lengths, less chlorophyll and lower photosynthesis stomatal conductance (Gs), but increased proline and antioxidant enzymes activity in leaf tissue. The $\mathrm{n}-\mathrm{TiO}_{2}$ promoted growth and photosynthetic performance of barley plants under salt stress. Sodium nitroprusside (SNP) supplied with $\mathrm{n}-\mathrm{TiO}_{2}$ counteracted deleterious effects of salinity on growth parameters. Enhanced superoxide dismutase (SOD), catalase (CAT) and ascorbate peroxidase (APX) activities with less malondialdehyde (MDA) were observed in presence of $100 \mu \mathrm{M}$ SNP. It is suggested that engineered nanoparticles and SNP-induced salt tolerance in barley are likely associated with increases in some antioxidant enzyme activities. Moreover, MDA and hydrogen peroxide $\left(\mathrm{H}_{2} \mathrm{O}_{2}\right)$ concentrations in the shoot of barley were alleviated by $\mathrm{n}-\mathrm{TiO}_{2}$ and $\mathrm{SNP}$ application. Taken together, based on all these data it can be concluded that $\mathrm{n}-\mathrm{TiO}_{2}$ with employing NO donor in the form of SNP might be a promising approach in counteracting the adverse effects of salinity stress on barley growth.
\end{abstract}

Key words: relative water content, salt stress, sodium nitroprusside.

\section{Introduction}

Nanomaterials are one of the most studied materials of the century that gave birth to a new branch of science known as nanotechnology. Engineered nanoparticles have been used in numerous industrial fields such as paints, inks, coatings, solar cells, plastics, soaps, antimicrobial agents, textiles, sunscreen, cosmetics, medicines and pharmaceuticals (Martínez-Fernández et al., 2017). Notably, the production of engineered nanoparticles is growing at an incredibly fast rate and will soon become a trillion-dollar industry. At this rate of production, nanomaterials can be released to the environment and have various influences on the biological systems, including plants (Jośko et al., 2017). Therefore, the agricultural section is greatly affected by employing nanoparticles. Engineered nanoparticles have enormous potential for being used as directed delivery systems for pesticides, fertiliser and other chemical compounds.

Nano titanium dioxide $\left(\mathrm{n}-\mathrm{TiO}_{2}\right)$ is the most widely produced nanoparticle. It was reported that up to two million tons per year of $\mathrm{n}-\mathrm{TiO}$ are produced worldwide (Larue et al., 2012 a). Recently, it has been indicated that different kinds of nano titanium such as anatase, rutile and brookite can influence plant growth
(Aghdam et al., 2016), enzyme activity (Song et al., 2012) and photosynthetic activity (Li et al., 2015).

Salinity is known as one of the most widespread abiotic stresses that contribute to decreased crop yields. This stress causes a series of morphological, physiological and biochemical changes which are associated with plant growth. Soil salinity makes osmotic stress in plants, as well as induces water imbalance, photosynthesis inhibition, lipid peroxidation, destruction of pigment and nutrient deficiency. Also, salinity induces excessive accumulation of reactive oxygen species (ROS) which causes oxidative damage to biomolecules. Notably, the exposure of plants to salinity stress causes ionic toxicity due to the accumulation of $\mathrm{Na}^{+}$and $\mathrm{Cl}^{-}$ions, which impairs growth and development of plants (Fatma et al., 2016). The plant tolerance to salinity is related to compatible compound accumulation, sufficient salt ion compartmentalisation, maintenance of cells, hormonal balance and nutrients homeostasis (Acosta-Motos et al., 2017).

Nitric oxide (NO), a water and lipid soluble gaseous free radical, was considered as a major signal molecule in plant biology (Shan, Yang, 2017). It plays multiple roles in the regulation of plant physiological

Please use the following format when citing the article:

Karami A., Sepehri A. 2018. Nano titanium dioxide and nitric oxide alleviate salt induced changes in seedling growth, physiological and photosynthesis attributes of barley. Zemdirbyste-Agriculture, 105 (2): 123-132 DOI 10.13080/z-a.2018.105.016 
processes and plant growth under abiotic stresses (Fatma et al., 2016). Furthermore, a few studies confirmed that NO can impact on the interaction of nanoparticles and plants growth (Chen et al., 2015). Barley is a major crop that ranks as the fourth most important cereal in terms of planting area. This plant is known as a salt-tolerant crop and is suitable for cultivating in saline lands.

It was confirmed, that nanomaterials can change the plant growth, but the different aspects of impact of nanomaterials on plant performance are not predictable and need to be explored. To our knowledge, the impacts of nanomaterials in plants are dependent on the plant species and physiochemical properties of nanomaterials. There is currently no information available about the possible effects (positive, negative or neutral) of $\mathrm{TiO}_{2}$ on barley growth under saline condition. Therefore, the purpose of this study was to investigate the impact of

A

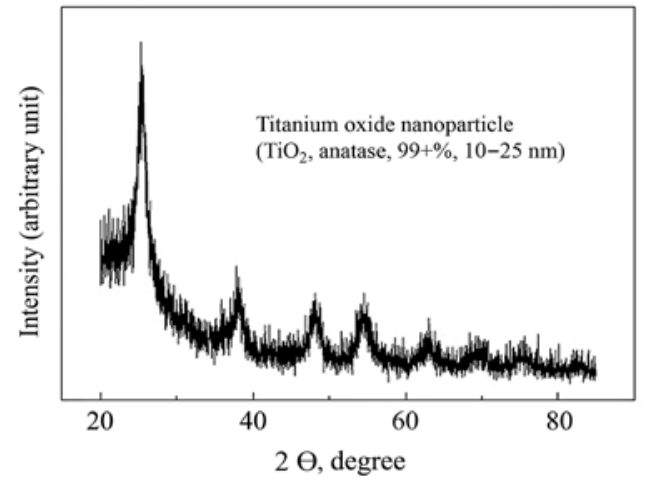

nano titanium dioxide $\left(\mathrm{n}-\mathrm{TiO}_{2}\right)$ alone or in combination with sodium nitroprusside (SNP) on the barley seedling growth based on some biochemical, physiological and photosynthetic characteristics under salinity stress.

\section{Materials and methods}

Characterisation of titanium dioxide ( $\mathrm{TiO}$ ) nanoparticles (NPS). In the current study, commercially available nano titanium dioxide $\left(\mathrm{n}-\mathrm{TiO}_{2}\right)$ : primary size - 10-25 nm, surface area - 200-240 $\mathrm{m}^{2} \mathrm{~g}^{-1}$, $\mathrm{pH}$ 6-6.5, bulk density $-0.24 \mathrm{~g} \mathrm{~cm}^{-3}$, true density $-3.9 \mathrm{~g} \mathrm{~cm}^{-3}$ and $99 \%$ purity, were used. The $n-\mathrm{TiO}_{2}$ was tested with $\mathrm{X}$-ray diffraction and transmission electron microscopy image (Fig. 1). The X-ray diffraction measurement showed that $\mathrm{TiO}_{2}$ nanoparticles used were all present in the anatase form.

B

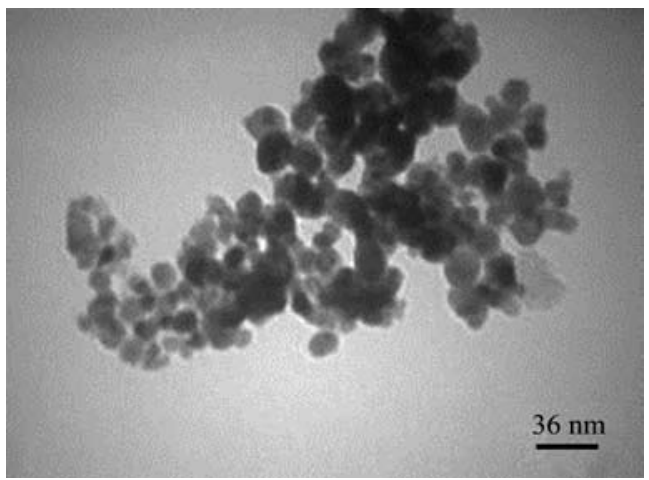

Figure 1. X-ray diffraction pattern (A) and transmission electron microscopy image (B) of titanium dioxide $\left(\mathrm{TiO}_{2}\right)$ nanoparticles

Treatments, experimental setup and growth conditions. This experiment was carried out in a factorial arrangement based on completely randomised design with three replications. Treatments consisted of three factors: 1) $\mathrm{TiO}_{2}$ nanoparticles $(0,500,1000$ and 2000 $\left.\mathrm{mg} \mathrm{kg}^{-1}\right)$, 2) sodium nitroprusside (SNP) as nitric oxide (NO) donor $(0$ and $100 \mu \mathrm{M})$ and 3$)$ salinity stress $(0$, 100 and $200 \mathrm{mM} \mathrm{NaCl})$. At the beginning, twenty seeds of barley (Hordeum vulgare L.) cultivar 'Afzal' were directly cultivated in pots $(14 \mathrm{~cm}$ diameter and $13 \mathrm{~cm}$ depth), containing $1.5 \mathrm{~kg}$ of soil (a clay loam soil with electric conductivity of $0.75 \mathrm{dSm}^{-1}$ and $\mathrm{pH}$ of 7.1). The concentrations of total $\mathrm{N}, \mathrm{P}, \mathrm{K}, \mathrm{Fe}, \mathrm{Zn}, \mathrm{Cu}, \mathrm{Mn}$ and $\mathrm{Mg}$ were $0.15 \%, 9.2,220,10.5,0.9,0.75,12$ and $90 \mathrm{mg} \mathrm{kg}^{-1}$, respectively. Nano titanium powder was added to the soil and mixed before seed cultivation. After plant growth and having them thinned, 12 plants remained in each pot and sodium chloride $(\mathrm{NaCl})$ was added gradually with irrigation. Then, sodium nitroprusside (SNP) was applied as foliar spray seven days after completion of salinity treatments. Plants were grown in a greenhouse: light supplemented with fluorescent lamps provided in the greenhouse for $16 \mathrm{~h}$ per day with an irradiance of $250 \mu \mathrm{mol} \mathrm{m} \mathrm{m}^{-2} \mathrm{~s}^{-1}$, the temperature of $28 / 18^{\circ} \mathrm{C}$ day/ night and $75 \%$ relative humidity, at the Department of Agronomy and Plant Breeding, Faculty of Agriculture, Bu-Ali Sina University, Hamadan, Iran, in 2017. After 40 days of plants growth (at the $30^{\text {th }}$ stage of Zadoks growth scale), we measured photosynthetic variables and began to harvest seedlings for studying their morphological and physiological indices.

Determination of seedling growth traits. At the harvest, the roots of seedling were carefully separated from soil to avoid damage. The lengths of the roots and shoots of barley seedlings were measured with a rectilinear scale. Five plants of similar size from the population were used to determine the root and shoot lengths.

Determination of relative water content $(R W C)$.

The RWC was measured according to the method of Tanentzap et al. (2015). A composite sample of leaf discs was taken and the fresh weight was measured, then the leaf discs were put into distilled water for four hours in low-light intensity to determine the turgid weight. Water remaining on the surface of the plants was blotted with filter paper. After that, the slices were dried for 48 hours at $72^{\circ} \mathrm{C}$ and the RWC was determined through the following equation: $\mathrm{RWC}=($ fresh weight - dry weight $)$ / (turgid weight - dry weight) $\times 100 \%$.

Determination of chlorophyll content. Total chlorophyll content was extracted from fresh materials $(0.5 \mathrm{~g})$ with $80 \%$ acetone solution as described by Arnon (1975). The resulting homogenate was centrifuged at $3000 \mathrm{~g}$ for $15 \mathrm{~min}$ and the absorbance of the supernatant was recorded by a spectrophotometer Spekol 2000 (Analytik Jena AG, Germany) at 645 and $663 \mathrm{~nm}$. The total chlorophyll (Chl) content was calculated by the following equation:

total Chl content $\left(\mathrm{mg} \mathrm{g}^{-1} \mathrm{FW}\right)=(20.2 \times \mathrm{D} 645+$ $8.02 \times \mathrm{D} 663) \times \mathrm{V} /(1000 \times \mathrm{W})$,

where D645 and D663 are the absorbance values at 645 and $663 \mathrm{~nm}$, respectively, V - volume of $80 \%(\mathrm{v} / \mathrm{v})$ acetone $(\mathrm{ml})$ and $\mathrm{W}-$ fresh weight $(\mathrm{FW})$ of sample $(\mathrm{g})$.

Determination of photosynthetic indices. Gas exchange variables of barley seedling leaves including net photosynthetic rate $(\mathrm{Pn})$, stomatal conductance (Gs) and transpiration rate (E) were measured using a portable photosynthesis system Li-COR 6400 (USA). The measurements were done on a sunny day at light 
saturating intensity, photosynthetically active radiation (PAR); $1000 \mu \mathrm{mol} \mathrm{m}^{-2} \mathrm{~s}^{-1}$, chamber block temperature was 28 , flow rate was kept at $800 \mathrm{mmol} \mathrm{s}^{-1}$ and $360 \mu \mathrm{mol} \mathrm{mol}^{-1}$ atmospheric carbon dioxide $\left(\mathrm{CO}_{2}\right)$ concentrations.

Determination of total soluble proteins (TSP). The soluble leaf protein content was estimated according to the method of Bradford (1976) using bovine serum albumin (BSA) as standard. The TSP were estimated $0.5 \mathrm{~g}$ of leaf tissues were ground with liquid nitrogen and then resuspended in extraction buffer containing $50 \mathrm{mM}$ Tricine-Tris buffer, $1 \mathrm{mM}$ ethylene diamine tetraacetic acid (EDTA), $1 \mathrm{mM}$ dithiothreitol, $1 \mathrm{mM}$ leupeptin, $1 \mathrm{mM}$ pepstatin and $1 \mathrm{mM}$ phenylmethylsulfonyl fluoride $(\mathrm{pH} \mathrm{7.4)}$. After centrifugation at $12000 \times \mathrm{g}$ for $30 \mathrm{~min}$ at $4{ }^{\circ} \mathrm{C}$ the absorbance of the supernatant was noted at $595 \mathrm{~nm}$ against a blank.

Determination of antioxidant enzymes. Fresh leaf tissues $(5 \mathrm{~g})$ were ground in liquid nitrogen and homogenised at $4^{\circ} \mathrm{C}$ in $1 \mathrm{ml}$ of $100 \mathrm{mM}$ potassium phosphate buffer ( $\mathrm{pH}$ 7.8). The homogenate was centrifuged at 12,000 rpm for $30 \mathrm{~min}$ and the supernatant was collected for enzymes assays.

Superoxide dismutase (SOD) (EC 1.15.1.1) activity was estimated according to the method of Giannopolitis and Ries (1977). The reaction mixture contained $1 \mu \mathrm{M}$ riboflavin, $12 \mathrm{mM}$ L-methionine, $0.1 \mathrm{mM}$ EDTA, $50 \mathrm{mM}$ sodium carbonate $\left(\mathrm{Na}_{2} \mathrm{CO}_{3}\right), 75 \mu \mathrm{M}$ nitro blue tetrazolium (NBT), $25 \mathrm{mM}$ sodium phosphate buffer (pH 6.8) and crude enzyme extract with a final volume of $3 \mathrm{~mL}$. SOD activity was assayed by measuring the ability of the enzyme extract to inhibit the photo reduction of NBT. Every step of the analysis was carried out in the dark. The mixture was illuminated for $15 \mathrm{~min}$ with a $100-\mathrm{W}$ lamp. For each sample, the same reaction mixture without illumination was prepared as the control. The absorbance was read at $560 \mathrm{~nm}$ in the spectrophotometer against reaction solution (blank). One unit of SOD was defined as the amount of enzyme which caused a $50 \%$ decrease in the SOD-inhibited NBT reduction. SOD activity is expressed in units per mg protein.

The activity of catalase (CAT) (EC 1.11.1.6) was determined using the method described by Aebi (1984) with minor modifications. It was measured in a reaction mixture of $3 \mathrm{ml}$ containing $50 \mathrm{mM}$ potassium phosphate buffer ( $\mathrm{pH} 7.8$ ), $10 \mathrm{mM} \mathrm{H}_{2} \mathrm{O}_{2}$ and crude enzyme extract. The decrease in the absorbance at $240 \mathrm{~nm}$ was recorded for $3 \mathrm{~min}$. The reaction started by adding hydrogen peroxide $\left(\mathrm{H}_{2} \mathrm{O}_{2}\right)$ and a decrease in absorbance was recorded at $240 \mathrm{~nm}$ for $1 \mathrm{~min}$. The CAT activity was calculated with an extinction coefficient $\left(39.4 \mathrm{mM}^{-1} \mathrm{~cm}^{-1}\right)$ and was expressed in units per $\mathrm{mg}$ protein.

Ascorbate peroxidase (APX) (EC 1.11.1.11) activity was assayed according to the method of Nakano and Asada (1981). It was measured in a reaction mixture of $3 \mathrm{ml}$ containing $50 \mathrm{mM}$ potassium phosphate buffer (pH 7.0), $0.1 \mathrm{mM}$ EDTA-Na, $0.5 \mathrm{mM}$ ascorbic acid, 0.1 $\mathrm{mM} \mathrm{H} \mathrm{O}_{2}$ and crude enzyme extract. The initial rate of the reaction using the extinction coefficient of ascorbate $\left(\varepsilon=2.8 \mathrm{mM}^{-1} \mathrm{~cm}^{-1}\right)$ at $290 \mathrm{~nm}$.

Determination of proline contents. Proline contents in leaf tissues were measured by the Bates et al. (1973) method. Leaf samples $(0.5 \mathrm{~g})$ were homogenised with $3 \%$ sulfosalicylic acid and then centrifuged at $10,000 \mathrm{rpm}$. Two $\mathrm{ml}$ of the supernatant was mixed with $2 \mathrm{ml}$ of ninhydrin reagent and the same volume of glacial acetic. The mixture was placed in a water bath for at $100^{\circ} \mathrm{C}$ for $1 \mathrm{~h}$. After cooling the reaction mixture, toluene was added and the absorbance of toluene phase was read at $520 \mathrm{~nm}$ with a spectrophotometer. Appropriate proline standards were included in the calculation of proline in the samples.

Determination of malonyldialdehyde (MDA) content. The concentration of MDA (lipid peroxidation) was determined based on the method of Heath and Packer (1968). Briefly, fresh leaves $(1 \mathrm{~g})$ were ground in $3 \mathrm{ml}$ of $0.1 \%(\mathrm{w} / \mathrm{v})$ trichloroacetic acid solution and centrifuged at $12,000 \mathrm{~g}$ for $20 \mathrm{~min}$. The supernatant $(3 \mathrm{~mL})$ was mixed with an equal volume of $0.5 \%(\mathrm{w} / \mathrm{v})$ thiobarbituric acid. The mixture was incubated at $95^{\circ} \mathrm{C}$ for $30 \mathrm{~min}$ and the reaction was stopped by placing in an ice bath and then centrifuged at $12000 \mathrm{~g}$ for $10 \mathrm{~min}$. The level of thiobarbituric acid-reactive substances was detected as specific absorbance at $532 \mathrm{~nm}$ by subtracting the non-specific absorbance at $600 \mathrm{~nm}$ and calculated using an extinction coefficient of $155 \mathrm{mM}^{-1} \mathrm{~cm}^{-1}$. The MDA content was computed based on its extinction coefficient of $155 \mathrm{mM}^{-1} \mathrm{~cm}^{-1}$ and expressed nmol g ${ }^{-1} \mathrm{FW}$.

Determination of hydrogen peroxide $\left(\mathrm{H}_{2} \mathrm{O}_{2}\right)$. The $\mathrm{H}_{2} \mathrm{O}_{2}$ content was determined according to Loreto and Velikova (2001). Briefly, leaf samples $(0.5 \mathrm{~g})$ were ground in an ice bath with $5 \mathrm{~mL}$ of $0.1 \%(\mathrm{w} / \mathrm{v})$ trichloroacetic acid and centrifuged at $10,000 \mathrm{rpm}$ for four min. Next, $0.5 \mathrm{~mL}$ of the supernatant was added to $0.5 \mathrm{~mL} 10 \mathrm{mM}$ potassium phosphate buffer ( $\mathrm{pH} 7.0)$ and $1 \mathrm{~mL} 1 \mathrm{M} \mathrm{KI}$ (potassium iodide). Finally, the absorbency of the supernatant was read at $390 \mathrm{~nm}$. The $\mathrm{H}_{2} \mathrm{O}_{2}$ content was calculated by comparison with a standard calibration curve prepared using different concentrations of $\mathrm{H}_{2} \mathrm{O}_{2}$.

Determination of $\mathrm{Na}^{+}$and $\mathrm{K}^{+}$concentration.

$\mathrm{Na}^{+}$and $\mathrm{K}^{+}$measurements were conducted according to Enders and Lehmann (2012) with minor modifications. Barley leaves were transferred to an oven at $72^{\circ} \mathrm{C}$ for $48 \mathrm{~h}$ and then the dried samples were crushed into powder using mortar and pestle. Following this, $0.2 \mathrm{~g}$ of plant material was added to $4 \mathrm{~mL}$ nitric acid. Samples were placed for $60 \mathrm{~min}$ in water bath at $65^{\circ} \mathrm{C}$ and then heated for $90 \mathrm{~min}$ at $100^{\circ} \mathrm{C}$. Next, tubes were allowed to cool before adding $0.2 \mathrm{~mL} \mathrm{H}_{2} \mathrm{O}_{2}$. Finally, $\mathrm{Na}^{+}$and $\mathrm{K}^{+}$concentrations were determined by using flame photometer.

Statistical analysis. All data presented are the mean values of three independent sets of experiments ( \pm standard error, SE). The statistical analysis was carried out using software $S A S$ 9.3. Significant differences among the treatment means were compared by least significant difference (LSD) tests $(P \leq 0.05)$.

\section{Results and discussion}

Root and shoot lengths. Based on the variance analysis of all data (data not shown), a significant effect between two-way interaction of salinity $\times \mathrm{n}-\mathrm{TiO}_{2}$, as well as salinity $\times$ SNP for the root length (Fig. 2) and a three-way interaction of salinity $\times \mathrm{n}-\mathrm{TiO}_{2} \times \mathrm{SNP}$ for the shoot length (Table 1) were observed in barley plants. Generally, with the increase of salinity concentration in saline medium, both root and shoot lengths of barley were significantly decreased as compared to the plants treated with distilled water.

The root length of seedlings reduced to $31.2 \%$ and $54 \%$ over non salinity treatment after exposure to 100 and $200 \mathrm{mM} \mathrm{NaCl}$, respectively (Fig. 2). Growth reduction under salinity conditions can be attributed to some of the physiological and biochemical processes such as carbon assimilation, nitrogen metabolism, enzyme activity, nutrient homeostasis and over-production of reactive oxygen species (ROS). Based on the interaction effect between $\mathrm{n}-\mathrm{TiO}_{2}$ and salinity, the length of the root was positively impacted by n- $\mathrm{TiO}$ treatments under both salt-stressed and non-stressed conditions. The n-TiO, at 500,1000 and $2000 \mathrm{mg} \mathrm{kg}^{-1}$ increased barley roots by 

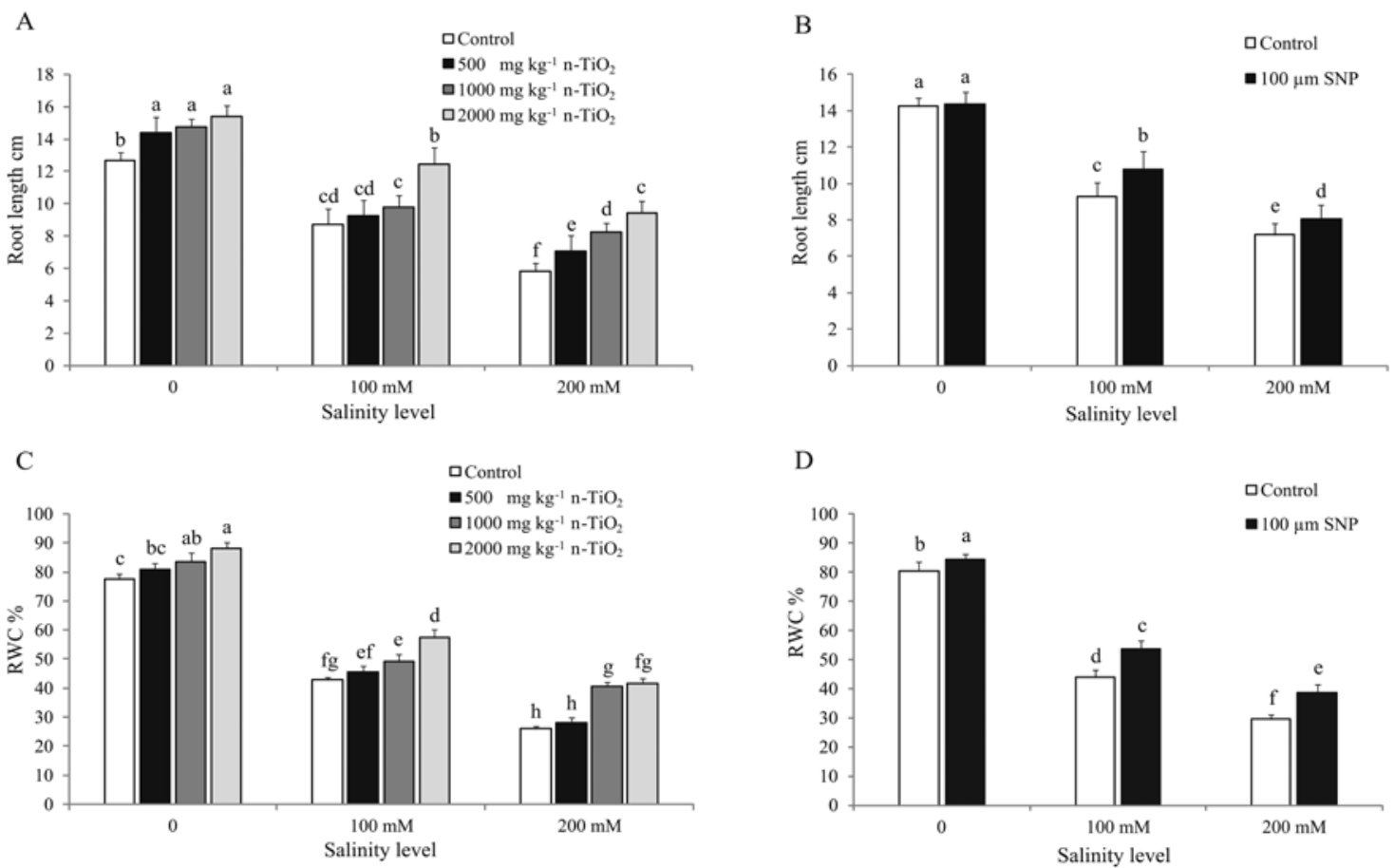

Note. Values with the same letter did not significantly differ at $p \leq 0.05$ levels based on LSD test.

Figure 2. Effects of nano titanium dioxide $\left(\mathrm{n}-\mathrm{TiO}_{2}\right)$ and salinity levels on root length $(\mathrm{A})$ and relative water content (RWC) (C), and sodium nitroprusside (SNP) as nitric oxide (NO) donor and salinity (NaCl) levels on root length (B) and RWC (D) of barley

Table 1. Shoot length (SL), photosynthetic rate (Pn), superoxide dismutase (SOD) activity, malondialdehyde (MDA), hydrogen peroxide $\left(\mathrm{H}_{2} \mathrm{O}_{2}\right)$ and total soluble protein (TSP) contents of barley in response to nano titanium dioxide $\left(\mathrm{n}-\mathrm{TiO}_{2}\right)$ and sodium nitroprusside $(\mathrm{SNP})$ as nitric oxide $(\mathrm{NO})$ donor under different salinity $(\mathrm{NaCl})$ levels

\begin{tabular}{|c|c|c|c|c|c|c|c|c|}
\hline \multicolumn{3}{|c|}{ Treatment } & \multirow{2}{*}{$\begin{array}{l}\mathrm{SL} \\
\mathrm{cm}\end{array}$} & \multirow{2}{*}{ 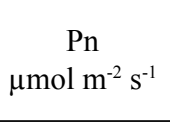 } & \multirow{2}{*}{$\begin{array}{c}\mathrm{SOD} \\
\mathrm{U} \mathrm{mg^{-1 }} \text { protein }\end{array}$} & \multirow{2}{*}{$\begin{array}{c}\text { MDA } \\
\text { nmol g-1 FW }\end{array}$} & \multirow{2}{*}{$\begin{array}{c}\mathrm{H}_{2} \mathrm{O}_{2} \\
\mu \mathrm{mol} \mathrm{g}{ }^{-1} \mathrm{FW}\end{array}$} & \multirow{2}{*}{$\begin{array}{c}\text { TSP } \\
\mathrm{mg} \mathrm{g}^{-1} \mathrm{FW}\end{array}$} \\
\hline $\begin{array}{c}\text { Salinity } \\
\mathrm{mM}\end{array}$ & $\begin{array}{l}\mathrm{n}-\mathrm{TiO}_{2} \\
\mathrm{mg} \mathrm{kg}^{-1}\end{array}$ & $\begin{array}{l}\text { SNP } \\
\mu \mathrm{M}\end{array}$ & & & & & & \\
\hline \multirow{8}{*}{0} & \multirow[b]{2}{*}{0} & 0 & $28.10 \pm 0.50$ & $19.30 \pm 1.00$ & $6.18 \pm 0.20$ & $8.90 \pm 0.80$ & $0.94 \pm 0.10$ & $43.90 \pm 0.60$ \\
\hline & & 100 & $9.00 \pm 1.00$ & $20.50 \pm 0.20$ & $6.90 \pm 1.00$ & $8.10 \pm 0.72$ & $0.80 \pm 0.11$ & $47.00 \pm 2.00$ \\
\hline & \multirow{2}{*}{500} & 0 & $29.70 \pm 0.52$ & $22.60 \pm 0.75$ & $7.20 \pm 0.50$ & $7.90 \pm 0.61$ & $0.88 \pm 0.09$ & $51.20 \pm 1.05$ \\
\hline & & 100 & $31.00 \pm 0.71$ & $23.57 \pm 1.10$ & $7.45 \pm 0.70$ & $7.20 \pm 0.42$ & $0.80 \pm 0.05$ & $53.15 \pm 1.40$ \\
\hline & \multirow{2}{*}{1000} & 0 & $31.20 \pm 1.05$ & $24.55 \pm 1.05$ & $7.60 \pm 0.60$ & $7.28 \pm 0.71$ & $0.78 \pm 0.03$ & $53.00 \pm 1.20$ \\
\hline & & 100 & $32.40 \pm 0.89$ & $24.55 \pm 0.60$ & $7.99 \pm 0.80$ & $7.04 \pm 0.15$ & $0.69 \pm 0.06$ & $55.10 \pm 1.60$ \\
\hline & \multirow{2}{*}{2000} & 0 & $33.00 \pm$ & $25.25=$ & $8.40 \pm 0.52$ & $6.30 \pm$ & $0.68 \pm 0.04$ & $56.50 \pm 0.50$ \\
\hline & & 100 & $33.20 \pm$ & $25.75=$ & $8.88 \pm 0.44$ & $5.90=$ & $0.62 \pm 0.07$ & 58.00 \\
\hline \multirow{8}{*}{100} & \multirow{2}{*}{0} & 0 & $17.00 \pm 1.00$ & $11.40 \pm 0.51$ & $9.90 \pm 0.56$ & $19.16 \pm 0.20$ & $1.55 \pm 0.02$ & $24.80 \pm 2.00$ \\
\hline & & 100 & $22.01 \pm 1.00$ & $17.25 \pm 1.00$ & $12.96 \pm 0.33$ & $17.07 \pm 0.57$ & $1.25 \pm 0.10$ & $36.50 \pm 0.40$ \\
\hline & \multirow{2}{*}{500} & 0 & $20.53 \pm 0.75$ & $14.25 \pm 0.59$ & $11.26 \pm 0.23$ & $17.40 \pm 0.48$ & $1.59 \pm 0.07$ & $30.50 \pm 1.50$ \\
\hline & & 100 & $21.00 \pm$ & 15. & $12.00 \pm 0.42$ & $14.19 \pm$ & $1.41 \pm 0.03$ & 32.06 \\
\hline & \multirow{2}{*}{1000} & 0 & $25.01 \pm 0.85$ & $16.20=$ & $12.19 \pm 0.71$ & $14.00 \pm$ & $1.45 \pm 0.04$ & 34.40 \\
\hline & & 100 & $24.03 \pm 0.90$ & $20.10 \pm 1.00$ & $16.00 \pm 0.54$ & $13.26 \pm 0.42$ & $1.17 \pm 0.12$ & $42.20 \pm 1.65$ \\
\hline & \multirow{2}{*}{2000} & 0 & $24.00 \pm 0.55$ & $19.15 \pm 0.68$ & $14.07 \pm 0.25$ & $14.69 \pm 0.36$ & $1.20 \pm 0.04$ & $42.30 \pm 2.00$ \\
\hline & & 100 & $27.00 \pm 1.04$ & $22.40 \pm 1.20$ & $15.14 \pm 0.60$ & $11.90 \pm 0.65$ & $1.15 \pm 0.06$ & $46.80 \pm 1.25$ \\
\hline \multirow{9}{*}{200} & \multirow[b]{2}{*}{0} & 0 & $12.20 \pm 0.71$ & $10.00 \pm 0.99$ & $19.52 \pm 0.50$ & $26.90 \pm 0.54$ & $2.55 \pm 0.05$ & $20.00 \pm 1.32$ \\
\hline & & 100 & $15.40 \pm 0.45$ & $12.50 \pm 1.12$ & $21.90 \pm 0.33$ & $21.62 \pm 0.42$ & $2.35 \pm 0.03$ & $25.00 \pm 2.03$ \\
\hline & \multirow{2}{*}{500} & 0 & $16.40 \pm 0.33$ & $10.00 \pm 0.57$ & $18.00 \pm 0.12$ & $25.28 \pm 0.28$ & $2.19 \pm 0.04$ & $20.00 \pm 1.48$ \\
\hline & & 100 & $18.00 \pm 0.88$ & $11.00 \pm 0.70$ & $22.00 \pm 0.50$ & $22.92 \pm 0.18$ & $1.75 \pm 0.07$ & $20.95 \pm 0.42$ \\
\hline & \multirow{2}{*}{1000} & 0 & $17.41 \pm 0.74$ & $13.57 \pm 1.00$ & $22.92 \pm 0.24$ & $24.50 \pm 0.23$ & $2.11 \pm 0.05$ & $27.14 \pm 1.54$ \\
\hline & & 100 & $21.11 \pm 0.77$ & $16.04 \pm 0.63$ & $25.28 \pm 0.77$ & $19.52 \pm 0.64$ & $1.91 \pm 0.03$ & $32.09 \pm 1.80$ \\
\hline & \multirow{2}{*}{2000} & 0 & $18.00 \pm 0.90$ & $12.20 \pm 0.67$ & $21.62 \pm 0.90$ & $19.00 \pm 0.32$ & $1.90 \pm 0.04$ & $24.41 \pm 1.74$ \\
\hline & & 100 & $22.81 \pm 1.00$ & $17.75 \pm 1.50$ & $26.90 \pm 1.10$ & $17.20 \pm 0.50$ & $1.45 \pm 0.06$ & $35.50 \pm 2.10$ \\
\hline & LSD & & 2.41 & 2.11 & 1.75 & 1.83 & 0.16 & 4.46 \\
\hline
\end{tabular}

Note. Values are the means of three independent replicates \pm SE; means are significantly different at $P \leq 0.05$ according to the LSD; FW - fresh weight.

$17.32,29.19$ and $38.28 \%$, respectively at $200 \mathrm{mM} \mathrm{NaCl}$ (Fig. 2). It seems that supply of $\mathrm{n}-\mathrm{TiO}_{2}$ stimulates the root and shoot growth by enhancing plant metabolism and cell division (Chutipaijit, 2015). It has been proposed that
n-TiO, through producing local oxidative stress, makes the cell wall pores extend which in consequence increases water flow in roots and root elongation (Larue et al., $2012 \mathrm{a}$; b). Additionally, n- $\mathrm{TiO}_{2}$, passed through apoplast, 
would loosen cell wall structure indirectly which may cause improvements in cell enlargement and plant growth (Mohammadi et al., 2016). In the current study, exogenous use of $100 \mu \mathrm{M}$ SNP increased root length, although the alleviatory effects of SNP under salinity were more efficient than non-stressed conditions (Fig. 2). The favourable effects of SNP (as NO donor) on plant growth under saline conditions may be related to the reduction of root-to-shoot translocation of $\mathrm{Na}^{+}$, scavenge leaves ROS and increase uptake of nutrient elements (Liu et al., 2014). According to three-way interaction effect between n-TiO, SNP and salinity, the supply of SNP in presence of n- $\mathrm{TiO}_{2}$ enhanced the shoot length as compared to treated or untreated plant with $\mathrm{n}-\mathrm{TiO}_{2}$ under saline conditions (Table 1). Recently it has been reported that NO can impact on the nanoparticles and plant growth (Chen et al., 2015).

Relative water content (RWC). Significant interactions were found in $n-\mathrm{TiO}_{2} \times$ salinity, as well as in SNP $\times$ salinity, for RWC of barley seedling. The RWC decreased by $44.8 \%$ and $66.31 \%$ at 100 and $200 \mathrm{mM}$ $\mathrm{NaCl}$, respectively (Fig. 2). All concentrations of n- $\mathrm{TiO}_{2}$ significantly increased the RWC of barley plants at different salt concentrations. The supply of $2000 \mathrm{mg} \mathrm{kg}^{-1}$ $\mathrm{n}-\mathrm{TiO}$, enhanced the RWC by $25.45 \%$ and $37.1 \%$, at 100 and $200 \mathrm{mM} \mathrm{NaCl}$. It is assumed that $\mathrm{n}-\mathrm{TiO}_{2}$ can create new pores in the plant cells and simplify the process of water uptake inside the cells (Singh et al., 2016). The higher surface reactivity of n-TiO might extend the pores of roots or make new ones which lead to higher water flow in roots (Larue et al., $2012 \mathrm{a}$; b). Thus, n-TiO is able to improve water absorption from root to shoot and improve RWC of barley leaves under saline conditions. Furthermore, the supply of SNP reduced the negative effect of salinity stress on RWC, as it was recovered by $6.35 \%$ and $7.03 \%$, respectively in 100 and $200 \mathrm{mM}$ $\mathrm{NaCl}$ (Fig. 2). It has already been proven that nitric oxide (NO) can enhance RWC and salinity tolerance of plants by affecting the activity of vacuolar $\mathrm{H}^{+}$-ATPase and $\mathrm{H}^{+}$-PPase, which provide the driving force for $\mathrm{Na}^{+} / \mathrm{H}^{+}$ exchange (Molassiotis et al., 2010). Two-way interaction of $\mathrm{n}-\mathrm{TiO}_{2} \times \mathrm{SNP}$ indicated that foliar application of SNP intensified positive impacts of $\mathrm{n}-\mathrm{TiO}_{2}$ on RWC of barley leaves (Table 2).

Table 2. Relative water content (RWC), stomatal conductance (Gs), catalase (CAT) activity, ascorbate peroxidase (APX) activity and proline content of barley in response to nano titanium dioxide (n- $\left.\mathrm{TiO}_{2}\right)$ and sodium nitroprusside (SNP) as nitric oxide (NO) donor

\begin{tabular}{|c|c|c|c|c|c|c|}
\hline \multicolumn{2}{|c|}{ Treatments } & \multirow[b]{2}{*}{$\begin{array}{c}\text { RWC } \\
\%\end{array}$} & \multirow[b]{2}{*}{$\begin{array}{c}\text { Gs } \\
\text { mmol m} \mathrm{m}^{-2} \mathrm{~s}^{-1}\end{array}$} & \multirow{2}{*}{$\begin{array}{c}\text { CAT } \\
\mathrm{U} \mathrm{mg}^{-1} \\
\text { protein }\end{array}$} & \multirow{2}{*}{$\begin{array}{c}\text { APX } \\
\mathrm{U} \mathrm{mg}^{-1} \\
\text { protein }\end{array}$} & \multirow[b]{2}{*}{$\begin{array}{c}\text { Proline } \\
\mathrm{mg} \mathrm{g}^{-1} \mathrm{FW}\end{array}$} \\
\hline $\begin{array}{l}\mathrm{n}-\mathrm{TiO}_{2} \\
\mathrm{mg} \mathrm{kg}^{-1}\end{array}$ & $\begin{array}{c}\text { SNP } \\
\mu \mathrm{M}\end{array}$ & & & & & \\
\hline \multirow{2}{*}{0} & 0 & $42.70 \pm 1.22$ & $195.44 \pm 4.50$ & $179.06 \pm 2.50$ & $0.84 \pm 0.07$ & $1.35 \pm 0.12$ \\
\hline & 100 & $54.80 \pm 1.10$ & $239.75 \pm 5.22$ & $217.86 \pm 4.10$ & $1.01 \pm 0.05$ & $1.66 \pm 0.17$ \\
\hline \multirow{2}{*}{500} & 0 & $48.70 \pm 0.59$ & $230.51 \pm 3.98$ & $200.66 \pm 3.80$ & $1.02 \pm 0.05$ & $1.71 \pm 0.09$ \\
\hline & 100 & $54.20 \pm 1.33$ & $239.95 \pm 7.27$ & $213.90 \pm 4.00$ & $1.12 \pm 0.03$ & $1.83 \pm 0.06$ \\
\hline \multirow[b]{2}{*}{1000} & 0 & $55.64 \pm 0.65$ & $263.51 \pm 5.60$ & $222.32 \pm 3.90$ & $1.14 \pm 0.06$ & $1.87 \pm 0.10$ \\
\hline & 100 & $59.89 \pm 0.50$ & $290.15 \pm 4.90$ & $242.33 \pm 4.26$ & $1.21 \pm 0.08$ & $1.98 \pm 0.11$ \\
\hline \multirow{2}{*}{2000} & 0 & $58.15 \pm 0.98$ & $268.85 \pm 6.50$ & $238.20 \pm 3.69$ & $1.23 \pm 0.03$ & $1.87 \pm 0.07$ \\
\hline & 100 & $66.53 \pm 0.88$ & $321.41 \pm 5.47$ & $267.33 \pm 4.44$ & $1.45 \pm 0.04$ & $2.24 \pm 0.05$ \\
\hline \multicolumn{2}{|c|}{ LSD } & 4.09 & 20.48 & 13.65 & 0.07 & 0.12 \\
\hline
\end{tabular}

Note. Values are the means of three independent replicates \pm SE; means are significantly different at $P \leq 0.05$ according to the LSD; FW - fresh weight.

Total chlorophyll. The interaction of $\mathrm{n}-\mathrm{TiO}_{2}$ $\times$ salinity and SNP $\times$ salinity were significant for total chlorophyll of barley seedling. The decline in total chlorophyll content in salt-affected barley plants might be attributed to the possible oxidation of chlorophyll under salt stress. Referring to Figure 3, the lowest chlorophyll content was achieved under $200 \mathrm{mM} \mathrm{NaCl}$. The total chlorophyll content was generally higher in those plants which were treated with $\mathrm{n}-\mathrm{TiO}_{2}$ concentrations compared to non-treated plants. The $\mathrm{n}-\mathrm{TiO}_{2}$ at 500,1000 and $2000 \mathrm{mg} \mathrm{kg}^{-1}$ boosted total chlorophyll by $35.2,52.1$ and $56.9 \%$, respectively under $200 \mathrm{mM} \mathrm{NaCl}$ (Fig. 3). It seems that $\mathrm{n}-\mathrm{TiO}_{2}$ can enhance total chlorophyll content due to its role in diminishing chlorophyll degradation and stimulate its biosynthesis under stress conditions (Mohammadi et al., 2014). In addition, a positive response from exogenous use of SNP was recorded for total chlorophyll content (Fig. 3). It is assumed that NO could promote the total chlorophyll, by protecting chlorophyll pigments from ROS. These results are in agreement with some earlier findings which confirmed that total chlorophyll content of plants exposed to SNP was increased (Liu et al., 2014). Generally, it is clear that an increase in chlorophyll content in presence of $\mathrm{n}-\mathrm{TiO}_{2}$ and SNP would be beneficial to plant photosynthesis, by allowing them to synthesise more light harvesting complexes to capture a greater amount of light energy.

Photosynthesis indices. Exposure to saline medium induced by salinity concentrations dramatically inhibited photosynthetic parameters such as net photosynthetic rate, stomatal conductance and transpiration rate in plants (Table 1, Fig. 3). Salinity stress at $200 \mathrm{mM} \mathrm{NaCl}$ decreased the photosynthetic rate, stomatal conductance and transpiration rate by about 48.1, 66.8 and $39.4 \%$, respectively as compared to no salinity. Photosynthesis reduction under salinity conditions may be related to the reduction in the level of the photosynthetic pigments, changes in antioxidant enzyme activities and reduction in nutrient uptake.

The three-way interaction effect between n-TiO, SNP and salinity was found statistically significant as to net photosynthetic rate of barley. The net photosynthetic rate improved in plants exposed to $\mathrm{n}-\mathrm{TiO}$, alone or combined with SNP under different levels of salinity (Table 1). In 100 and $200 \mathrm{mM} \mathrm{NaCl}$, the highest photosynthetic rate was recorded at $2000 \mathrm{mg} \mathrm{kg}^{-1}$ with the supply of SNP under 100 and $200 \mathrm{mM} \mathrm{NaCl}$. Also, n-TiO (2000 $\left.\mathrm{mg} \mathrm{kg}^{-1}\right)$ remarkably enhanced stomatal conductance by $31.07 \%$ and $24.8 \%$ and transpiration rate about $26.4 \%$ and $39.05 \%$ under 100 and $200 \mathrm{mM} \mathrm{NaCl}$ (Fig. 3). It is assumed that $\mathrm{n}-\mathrm{TiO}_{2}$ enhances the photosynthetic carbon assimilation by promoting chlorophyll content and activating rubisco activase. It was proved earlier, in the presence of $n-\mathrm{TiO}_{2}$, $\mathrm{CO}_{2}$ assimilation and plant photosynthesis were boosted by over expression of rubisco activase (Yamori et al., 2012). In addition, $\mathrm{n}-\mathrm{TiO}_{2}$ attributed to its photo catalytic property can hydrolyse water into oxygen, protons and electrons, in which the produced proton and electron go 

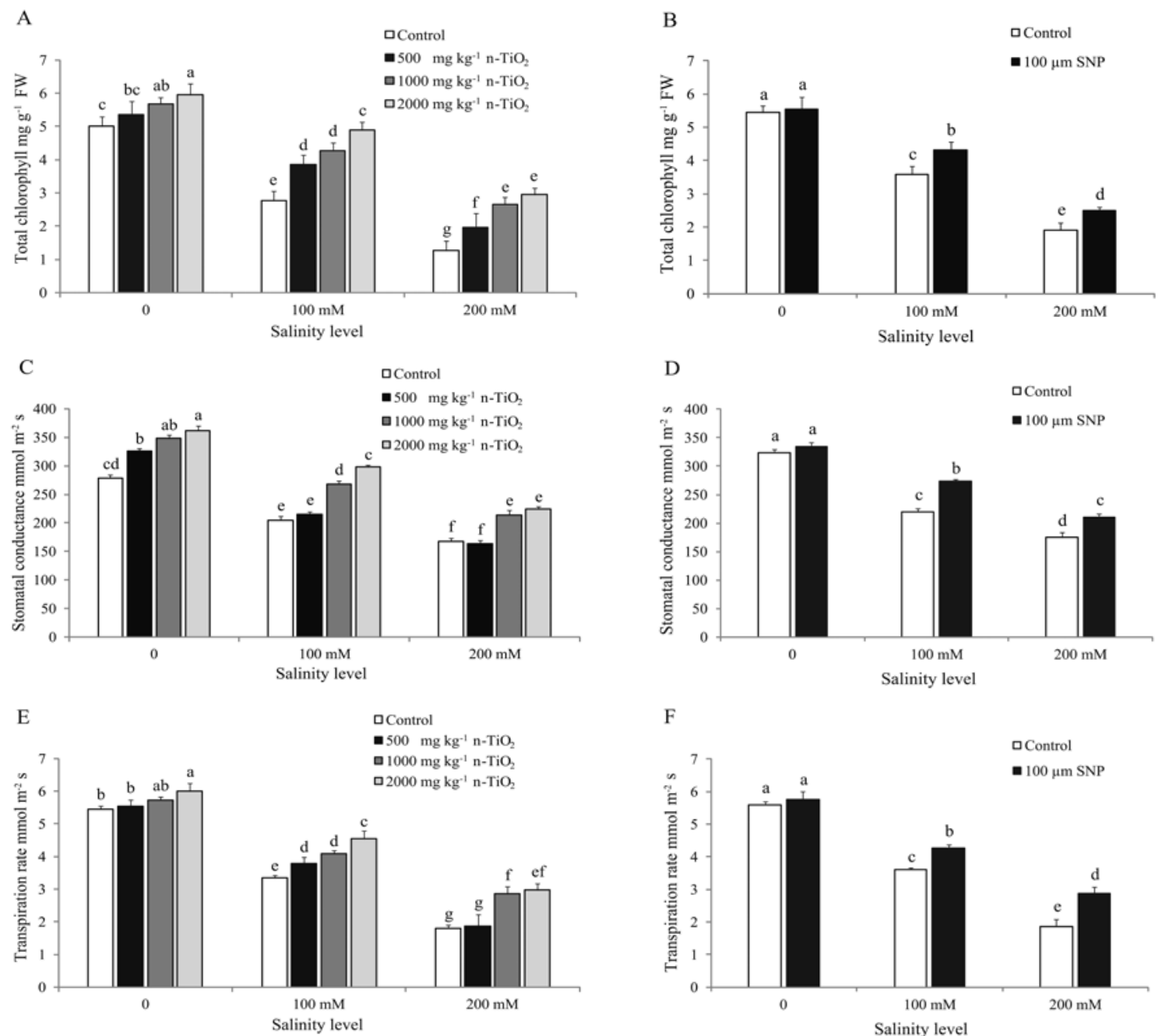

Note. Values with the same letter did not significantly differ at $p \leq 0.05$ levels based on LSD test.

Figure 3. Effects of nano titanium dioxide $\left(\mathrm{n}-\mathrm{TiO}_{2}\right)$ and salinity $(\mathrm{NaCl})$ levels on total chlorophyll $(\mathrm{A})$, stomatal conductance (C) and transpiration rate (E), and sodium nitroprusside (SNP) as nitric oxide (NO) donor and salinity levels on total chlorophyll (B), stomatal conductance (D) and transpiration rate (F) of barley

into an electron transfer chain of plants in the light reaction stage, therefore, enhancing the speed of photosynthesis (Mingyu et al., 2007). In other words, $\mathrm{n}-\mathrm{TiO}_{2}$ can increase the plant photosynthesis through improving the first photosystem light energy that is absorbed by chloroplast membrane and transferred to the second photosystem. Similarly, foliar application of $100 \mu \mathrm{M}$ SNP had positive impacts on stomatal conductance and transpiration rate of barley plants under stress conditions (Fig. 3). Based on two-way interaction effect of $\mathrm{n}-\mathrm{TiO}_{2} \times \mathrm{SNP}$, application of SNP heighten the impacts of $\mathrm{n}^{2} \mathrm{TiO}$, on some of the photosynthetic parameters of barley (Table 2). In this regard, plants exposed to $2000 \mathrm{mg} \mathrm{kg} \mathrm{kn}^{-1} \mathrm{n}-\mathrm{TiO}_{2}$ with SNP caused stimulated stomatal conductance by about $16.51 \%$ compared with $\mathrm{n}-\mathrm{TiO}_{2}$ treatment alone. It seems that nitric oxide (NO) can mitigate the diminishing of photosynthetic rate induced by non-stomatal factors and damaged by photo inhibition to the photosynthetic system under salinity stress (Fatma et al., 2016). The favourable impacts of SNP on plant photosynthesis, due to the ability of SNP to increase chlorophyll synthesis and diminish chlorophyll degradation, were pointed out by other researchers (Liu et al., 2014).

Total soluble proteins (TSP). A dose-dependent decline in TSP was recorded in plants treated with $\mathrm{NaCl}$ as salinity stress agent, so soluble proteins dropped to as low as $20 \mathrm{mg} \mathrm{g}^{-1} \mathrm{FW}$ under $200 \mathrm{mM} \mathrm{NaCl}$ (Table 1). The protein content decreased during salinity stress may be due to denaturation and irreversible damage to protein structure as a result of free radical invasion. Under such condition, plants protect their protein content by producing ROS scavenging antioxidant enzymes. In this study, the three-way interaction effect of studied factors showed that $\mathrm{n}-\mathrm{TiO}_{2}$ and SNP significantly affected TSP of barley under salinity stress. The highest TSP was recorded at $2000 \mathrm{mg} \mathrm{kg}^{-1} \mathrm{n}-\mathrm{TiO}_{2}$ and SNP (Table 1). Combined treatment of $\mathrm{n}-\mathrm{TiO}_{2}$ and SNP promoted TSP by about $47 \%$ and $43.6 \%$ under 100 and $200 \mathrm{mM} \mathrm{NaCl}$. It seems that $\mathrm{n}-\mathrm{TiO}_{2}$ and SNP protect TSP by promoting the activity of antioxidant enzymes. Furthermore, n-TiO may stimulate nitrogen metabolism by increasing the absorption of nitrate and accelerating conversion of inorganic form of nitrogen. Other researchers confirmed that employing SNP can enhance the TSP of plants under stress condition by boosting the synthesis of protein, inhibition of protein denaturation and contributing the better balance between carbon and nitrogen metabolism as a result of SNP application (Li et al., 2008).

Superoxide dismutase (SOD), catalase (CAT) and ascorbate peroxidase $(A P X)$ activity. The activity of SOD, CAT and APX enzymes sharply increased in response to $\mathrm{NaCl}$ treatment and indicated clear salinity- 
dependent trends (Table 1, Fig. 4). The three-way interaction effect between $\mathrm{n}-\mathrm{TiO}_{2}, \mathrm{SNP}$ and salinity was found significant for SOD activity of barley. The SOD activity was increased in the presence of $n-\mathrm{TiO}_{2}$ and SNP treatments. The highest SOD activity was recorded at $2000 \mathrm{mg} \mathrm{kg}^{-1} \mathrm{n}-\mathrm{TiO}$ with supply of $100 \mu \mathrm{m} \mathrm{SNP}$ under $200 \mathrm{mM} \mathrm{NaCl}$ (Table 1). A similar effect was observed for CAT and APX activities in the presence of $\mathrm{n}-\mathrm{TiO}$ (Fig. 4). It seems that $\mathrm{n}-\mathrm{TiO}_{2}$ inhibited $\mathrm{ROS}$ accumulation by increasing antioxidant enzymes activity. Increased antioxidant activities represent that $\mathrm{n}-\mathrm{TiO}_{2}$ induced stress was not severe enough to ruin the antioxidant system in the plants, rather activated it as a matter of defence and subsequently, it led to plant growth (Li et al., 2015). It was proved earlier that the presence of $n-\mathrm{TiO}_{2}$ in the cell probably causes signal pathways, which results in regulated metabolic changes against oxidative stress (Mohammadi et al., 2014). The increasing effect of $\mathrm{n}-\mathrm{TiO}_{2}$ on the antioxidant enzymes activity of tomato plants was pointed out by other researchers (Song et al., 2013). Also, a statistically significant increase in CAT and APX activities was observed in plants treated with $100 \mu \mathrm{m}$ SNP compared to the non-treated plants with SNP under $\mathrm{NaCl}$ levels. Using SNP increased CAT and APX activities by $9.73 \%$ and $16.1 \%$ under $200 \mathrm{mM}$ $\mathrm{NaCl}$ (Fig. 4). According to two-way interaction effect of
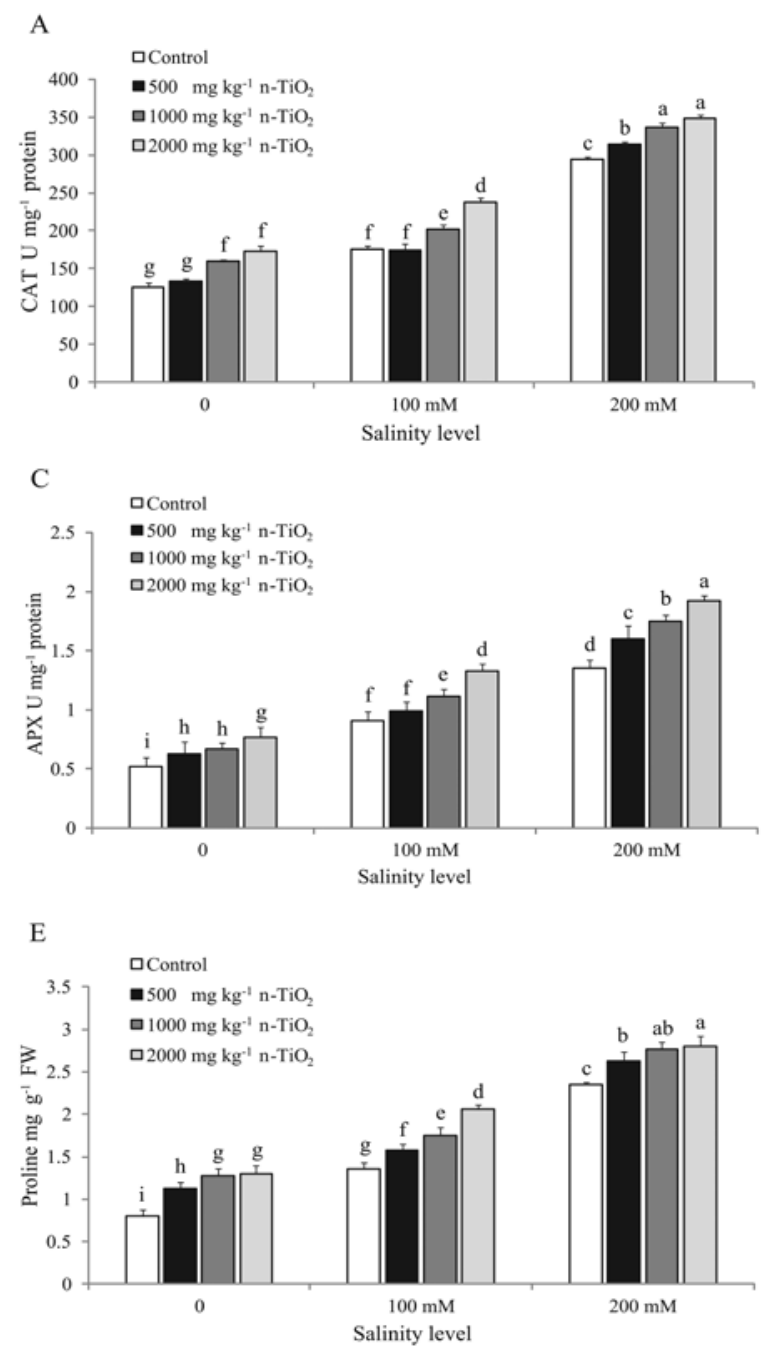

$\mathrm{n}-\mathrm{TiO}_{2} \times \mathrm{SNP}$, exogenous application of SNP increased the favourable impact of $\mathrm{n}-\mathrm{TiO}_{2}$ on CAT and APX activities (Table 2). The foliar spray of $100 \mu \mathrm{M}$ SNP in the presence of $2000 \mathrm{mg} \mathrm{kg}^{-1} \mathrm{n}-\mathrm{TiO}_{2}$ enhanced CAT and APX activities by $10.89 \%$ and $15.17 \%$ over corresponding treatments of $\mathrm{n}-\mathrm{TiO}_{2}$. It is assumed that $\mathrm{NO}$ may activate an antioxidant signalling pathway and play a protective role in plants against salinity stress. Several studies showed that exogenous application of NO promoted the antioxidant activity under various abiotic stresses ( $\mathrm{Li}$ et al., 2008; Liu et al., 2014).

Proline content. A considerable increase in the proline content of barley plants was observed in the response of $\mathrm{n}-\mathrm{TiO}_{2}, \mathrm{SNP}$ and $\mathrm{NaCl}$ (Fig. 4). Barley plants may cope with cell dehydration by accumulation of proline under salinity stress. Additionally, proline contributes to stabilizing subcellular structures in cell cytosol. According to the two-way interaction effect of $\mathrm{n}-\mathrm{TiO}_{2}$ and salinity, with the rise of salinity concentration, the proline content increased. Also, a further increase was observed in plants treated with $\mathrm{n}-\mathrm{TiO}_{2}$ under both salt-stressed and non-stressed conditions. Referring to Figure 4, application of $\mathrm{n}-\mathrm{TiO}_{2}$ at 500, 1000 and $2000 \mathrm{mg}$ $\mathrm{kg}^{-1}$ enhanced proline content by about $13.9,22.28$ and $33.98 \%$, respectively under $100 \mathrm{mM} \mathrm{NaCl}$. The induction of proline accumulation in response to $\mathrm{n}-\mathrm{TiO}_{2}$ may be due
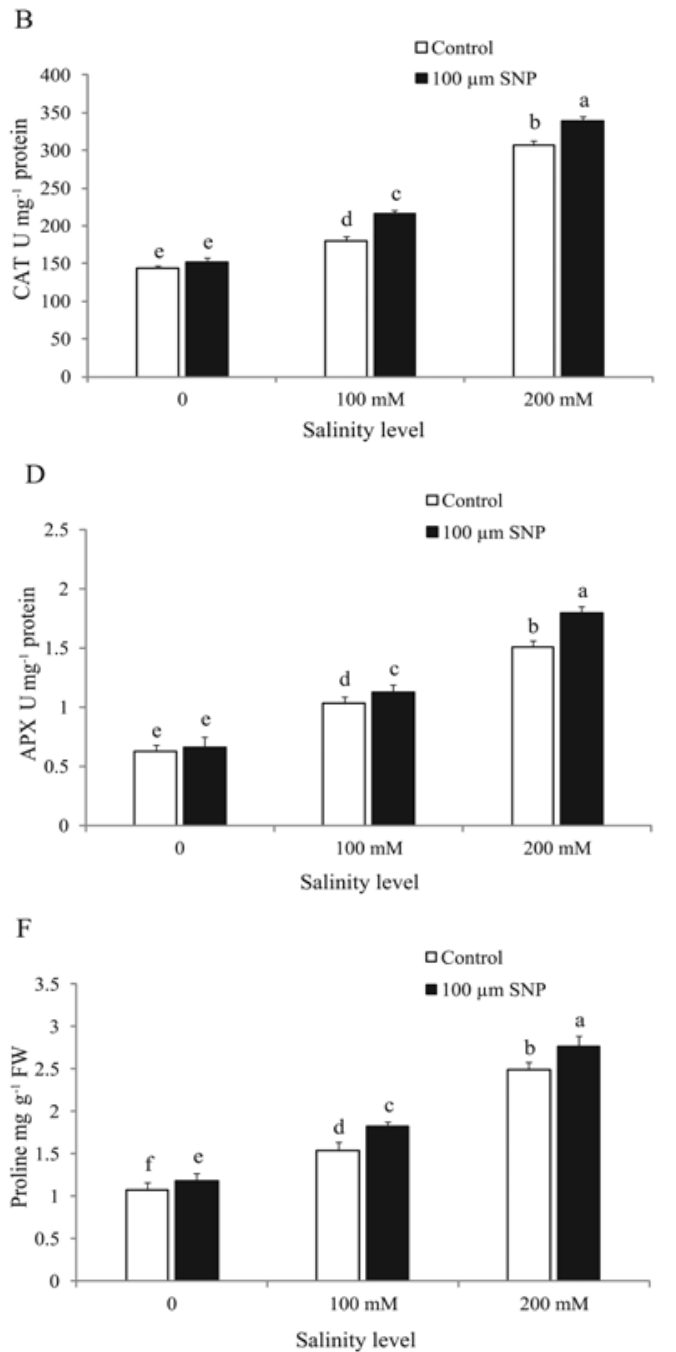

Note. Values with the same letter did not significantly differ at $p \leq 0.05$ levels based on LSD test.

Figure 4. Effects of nano titanium dioxide $\left(\mathrm{n}-\mathrm{TiO}_{2}\right)$ and salinity $(\mathrm{NaCl})$ levels on activity of catalase (CAT) (A), ascorbate peroxidase (APX) (C) and proline content (E), and sodium nitroprusside (SNP) as nitric oxide (NO) donor and salinity levels on activity of CAT (B), APX (D) and proline content (F) of barley 
to an activation of proline synthesis through glutamate pathway. There are some reports that confirmed proline content was promoted in plants treated with n-TiO, (Mohammadi et al., 2014; 2016). The foliar application of $100 \mu \mathrm{M}$ SNP also considerably raised proline content by $15.8 \%$ and $10.1 \%$ under 100 and $200 \mathrm{mM} \mathrm{NaCl}$ (Fig. 4). Based on results, a significant interaction was observed between n-TiO, and SNP. Foliar spray of SNP increased the positive impact of $\mathrm{n}-\mathrm{TiO}_{2}$ on the proline content of barley plants (Table 2). It was proved that exogenous SNP can adjust the biosynthesis of proline; as the pyrroline-5-carboxylate synthase $\left(\mathrm{P}_{5} \mathrm{C}_{\mathrm{S}}\right)$ activity increased and the pyruvate dehydrogenase $(\mathrm{PDH})$ activity decreased, the accumulation of proline accelerated (Fan et al., 2012). Notably, $\mathrm{P}_{5} \mathrm{C}_{\mathrm{S}}$ played a role in controlling the level of proline in plants and PDH is the key enzyme that catalyses proline degradation. The positive effects of $\mathrm{NO}$ on proline content of cotton plants were reported by other researchers (Liu et al., 2014).

Malondialdehyde (MDA) content. Based on results, there was a significant three-way interaction between salinity, $\mathrm{n}-\mathrm{TiO}_{2}$ and SNP. Salinity stress caused a considerable increase in the MDA content of barley leaves. The highest MDA content $\left(26.90 \mathrm{nmol} \mathrm{g}^{-1} \mathrm{FW}\right)$ was recorded at $200 \mathrm{mM} \mathrm{NaCl}$ (Table 1). It seems excessive accumulation of $\mathrm{Na}^{+}$in the plants, by overproduction of ROS, had toxic effects on the barley cell membrane and increased MDA content. The $\mathrm{n}-\mathrm{TiO}_{2}$ treatments with or without SNP declined MDA content in comparison with non-treated plants with $\mathrm{n}-\mathrm{TiO}_{2}$ and SNP. Notably, combined treatments were more efficient than sole use in diminishing MDA content under salinity levels. Under salinity conditions, the lowest MDA was measured at $\mathrm{n}-\mathrm{TiO}_{2}$ (particularly $2000 \mathrm{mg} \mathrm{kg}{ }^{-1}$ ) $+100 \mu \mathrm{M}$ SNP (Table 1). Reduction of MDA content in plants treated with $\mathrm{n}$ - $\mathrm{TiO}$ may be attributed to stabilized composition of their membranes. It seems that $\mathrm{n}-\mathrm{TiO}_{2}$ can alleviate deterrent impacts of salinity on the cell membrane by promoting antioxidants enzyme activity. The beneficial roles of n- $\mathrm{TiO}_{2}$
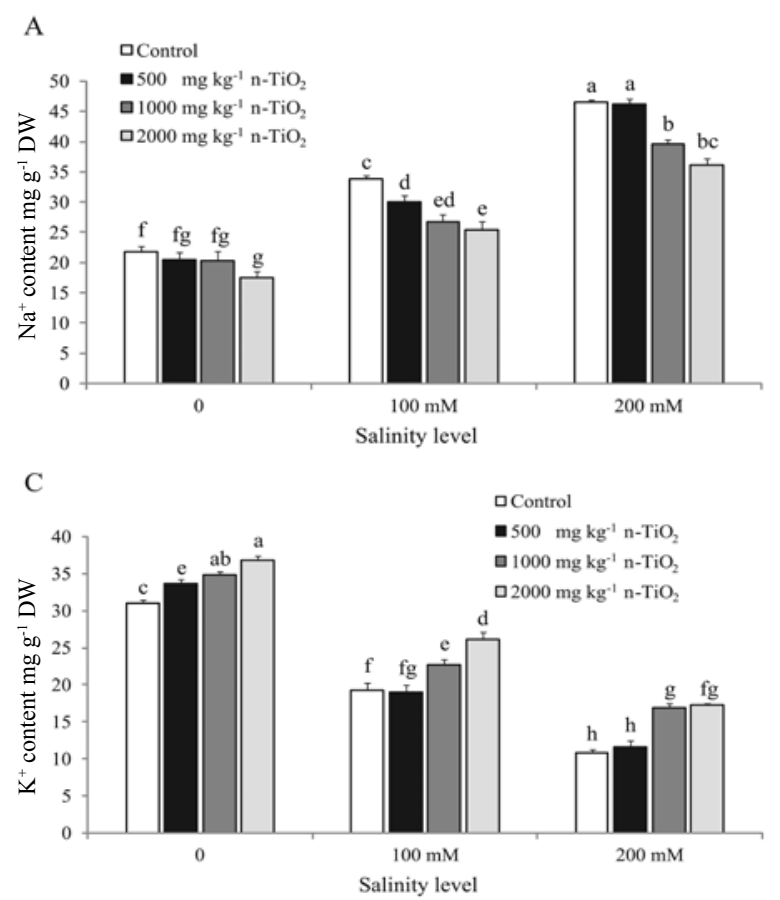

on decreasing MDA under stressful conditions have been reported previously (Mohammadi et al., 2013). Moreover, the application of exogenous NO in the form of SNP not only declined the MDA, but also improved the beneficial role of $\mathrm{n}-\mathrm{TiO}_{2}$ in decreasing MDA content under salinity conditions. It is proved that NO can reduce membrane injury by dehydration and improve the water status of plants; also NO can eliminate the over-accumulation of ROS under salinity stress (Liu et al., 2014).

Hydrogen peroxide $\left(\mathrm{H}_{2} \mathrm{O}_{2}\right)$ content. The results revealed significant impacts of salinity, $\mathrm{n}-\mathrm{TiO}_{2}, \mathrm{SNP}$ and their interaction on the $\mathrm{H}_{2} \mathrm{O}_{2}$ content of barley plants. A dose-dependent increase in $\mathrm{H}_{2} \mathrm{O}_{2}$ content was recorded in plants treated with $\mathrm{NaCl}$ as salinity stress agent. The $\mathrm{H}_{2} \mathrm{O}_{2}$ content of n-TiO-treated plant was lower than untreated plants (Table 1). The data showed that foliar spray of 100 $\mu \mathrm{M}$ NO donor enhanced the positive impact of $\mathrm{n}-\mathrm{TiO}_{2}$ on reducing $\mathrm{H}_{2} \mathrm{O}_{2}$ content. The supply of $\mathrm{n}-\mathrm{TiO}_{2}$ (especially $2000 \mathrm{mg} \mathrm{kg}^{-1}$ ) plus SNP reduced $\mathrm{H}_{2} \mathrm{O}_{2}$ content by about $25.80 \%$ and $43.1 \%$, respectively under 100 and $200 \mathrm{mM}$ $\mathrm{NaCl}$ (Table 1). The altered pattern of the $\mathrm{H}_{2} \mathrm{O}_{2}$ content indicates that $\mathrm{n}-\mathrm{TiO}$ may motivate some metabolisms such as defence mechanism when ROS accumulate. In addition, the $\mathrm{H}_{2} \mathrm{O}_{2}$ reduction in the presence of $\mathrm{n}-\mathrm{TiO}_{2}$ may be related to the ability of $\mathrm{Ti}^{+} / \mathrm{Ti}^{+}$to oxidize/reduce $\mathrm{O}_{-}^{-} / \mathrm{O}_{2}$ to $\mathrm{O}_{2}^{-} /$ $\mathrm{H}_{2} \mathrm{O}_{2}$ (Lei et al., 2008). Also, it was shown that application of $\mathrm{NO}$ donors resulted in decreased $\mathrm{H}_{2} \mathrm{O}_{2}$ content by increasing antioxidant enzymes (Çelik, Eraslan, 2015).

$\mathrm{Na}^{+}$and $\mathrm{K}^{+}$contents. The interaction between $\mathrm{n}-\mathrm{TiO}_{2} \times$ salinity, as well as $\mathrm{SNP} \times$ salinity was significant with respect to $\mathrm{Na}^{+}$and $\mathrm{K}^{+}$. With the rise of salinity concentration an increase in amount of $\mathrm{Na}^{+}$and a decrease in $\mathrm{K}^{+}$content were observed in barley leaves (Fig. 5). Salinity at 100 and $200 \mathrm{mM} \mathrm{NaCl}$ declined the $\mathrm{K}^{+}$content by about $37.6 \%$ and $64.9 \%$, respectively as compared to non-salinity treatment. In general, higher $\mathrm{Na}^{+}: \mathrm{K}^{+}$ratios in plants under stress conditions indicate metabolic disorders, such as a reduction of protein synthesis and enzyme activity, as well as an increase in membrane
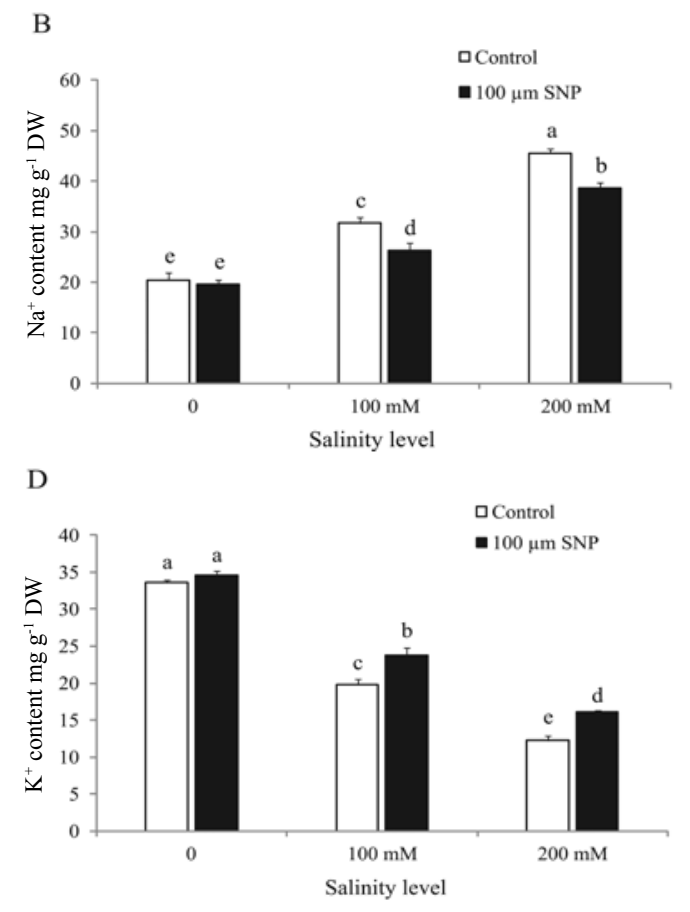

Note. Values with the same letter did not significantly differ at $p \leq 0.05$ levels based on LSD test.

Figure 5. Effects of nano titanium dioxide $\left(\mathrm{n}-\mathrm{TiO}_{2}\right)$ and salinity $(\mathrm{NaCl})$ levels on $\mathrm{Na}^{+}(\mathrm{A})$ and $\mathrm{K}^{+}(\mathrm{C})$ content of barley, and sodium nitroprusside (SNP) as nitric oxide (NO) donor and salinity levels on $\mathrm{Na}^{+}(\mathrm{B})$ and $\mathrm{K}^{+}(\mathrm{D})$ content of barley 
permeability. In the current study, under salinity stress, the $\mathrm{Na}^{+}$and $\mathrm{K}^{+}$contents were influenced significantly by n- $\mathrm{TiO}_{2}$ dosages compared to non $\mathrm{TiO}_{2}$ treatment (Fig. 5). Nano-TiO at 500, 1000 and $2000 \mathrm{mg} \mathrm{kg}^{-1}$ decreased $\mathrm{Na}^{+}$content by $0.7,15.06$ and $22.20 \%$ and increased $\mathrm{K}^{+}$ content by $7.02,35.87$ and $37.17 \%$ at $200 \mathrm{mM} \mathrm{NaCl}$. It is known that $\mathrm{n}-\mathrm{TiO}_{2}$ is able to change the balance between sodium and potassium uptake in plant roots by increasing the activity of plasma membrane $\mathrm{H}^{+}$-ATPase. In plants, $\mathrm{H}^{+}$-ATPase in plasma membrane plays an important role in the transport action of multiple ions. Moreover, with the supply of $100 \mu \mathrm{M}$ SNP to the plants $\mathrm{Na}^{+}$content significantly decreased while $\mathrm{K}^{+}$contents increased in the leaves under different levels of salinity (Fig. 5). It was proved earlier, NO can promote the expression of plasma membrane PM H $\mathrm{H}^{+}$-ATPase which is involved in $\mathrm{Na}^{+}$and $\mathrm{K}^{+}$transportation (Corpas et al., 2011).

\section{Conclusions}

1. The results of our study demonstrated that nano titanium dioxide $\left(\mathrm{n}-\mathrm{TiO}_{2}\right)$ particularly $2000 \mathrm{mg} \mathrm{kg}^{-1}$ promoted the growth and photosynthetic performance of barley seedlings under salinity stress. The n-TiO, was found to aid in strengthening the antioxidant enzyme activities which were due to the up-regulation of antioxidant defence in barley plants. Additionally, n- $\mathrm{TiO}_{2}$ can decrease the inhibition impacts of salinity stress by improving relative water content (RWC), chlorophyll content and net photosynthetic rate $(\mathrm{Pn})$.

2. Exogenous application of nitric oxide (NO) in the form of sodium nitroprusside (SNP) improved salt stress tolerance of barley seedlings due to enhancing antioxidant enzymes activity. The decrease in malondialdehyde (MDA) and hydrogen peroxide $\left(\mathrm{H}_{2} \mathrm{O}_{2}\right)$ indicated that oxidative stress which occurred under salinity stress was alleviated by SNP application. Moreover, employing NO donor promoted the favourable impacts of $\mathrm{n}-\mathrm{TiO}_{2}$ on growth, physiological and photosynthesis attributes of barley seedlings.

3 . The assessment of the results allows us to conclude that in the presence of $\mathrm{n}-\mathrm{TiO}_{2}$, employing NO donor (SNP) might be a promising approach in counteracting the adverse effects of salinity on barley growth. Future research is needed to show the impacts of $\mathrm{n}-\mathrm{TiO}_{2}$ and $\mathrm{NO}$ on gene expression of antioxidant enzymes and photosynthetic enzymes of barley plants.

\section{Acknowledgements}

Financial support for this work was granted by the Department of Agronomy and Plant Breeding, Faculty of Agriculture, Bu-Ali Sina University, Hamadan, Iran.

Received 26072017 Accepted 11032018

\section{References}

1. Acosta-Motos J. R., Ortuño M. F., Bernal-Vicente A., Diaz-Vivancos P., Sanchez-Blanco M. J., Hernandez J. A. 2017. Plant responses to salt stress: adaptive mechanisms. Agronomy, 7 (1): 1-37. https://doi.org/10.3390/agronomy7010018

2. Aebi H. 1984. Catalase in vitro. Methods in Enzymology, 105 (1): 121-126. https://doi.org/10.1016/S0076-6879(84)05016-3

3. Aghdam M. T. B., Mohammadi H., Ghorbanpour M. 2016 Effects of nanoparticulate anatase titanium dioxide on physiological and biochemical performance of Linum usitatissimum (Linaceae) under well-watered and drought stress conditions. Rrazilian Iournal of Rotany, 39 (1):139-146. https://doi.org/10.1007/s40415-015-0227-X
4. Arnon I. 1975. Physiological principles of dryland crop production. Gupta U. S. (ed.). Physiological aspects of dryland farming, $391 \mathrm{p}$.

5. Bates L., Waldren R., Teare I. 1973. Rapid determination of free proline for water-stress studies. Plant and Soil, 39 (1): 205-207. https://doi.org/10.1007/BF00018060

6. Bradford M. M. 1976. A rapid and sensitive method for the quantitation of microgram quantities of protein utilizing the principle of protein-dye binding. Analytical Biochemistry, 72 (1): 248-254.

https://doi.org/10.1016/0003-2697(76)90527-3

7. Çelik A., Eraslan F. 2015. Effects of exogenous nitric oxide on mineral nutrition and some physiological parameters of maize grown under salinity stress. Ziraat Fakültesi Dergisi, Süleyman Demirel Üniversitesi, 10 (1): 55-64 (in Turkish).

8. Chen J., Liu X., Wang C., Yin S. S., Li X. L., Hu W. J. Simon M., Shen Z. J., Xiao Q., Chu C. C. 2015. Nitric oxide ameliorates zinc oxide nanoparticles-induced phytotoxicity in rice seedlings. Inurnal of Hazardous Materials, 297 (1): 173-182. https://doi.org/10.1016/j.jhazmat.2015.04.077

9. Chutipaijit S. 2015. Establishment of condition and nanoparticle factors influencing plant regeneration from aromatic rice (Oryza sativa). International Journal of Agriculture and Riologv. 17 (5): 1049-1054.

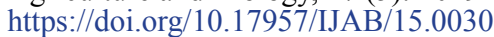

10. Corpas F. J., Leterrier M., Valderrama R., Airaki M., Chaki M., Palma J. M., Barroso J. B. 2011. Nitric oxide imbalance provokes a nitrosative response in plants under ahintic stress. Plant Science, 181 (5): 604-611. https://doi.org/10.1016/j.plantsci.2011.04.005

11. Enders A., Lehmann J. 2012 . Comparison of wet-digestion and dry-ashing methods for total elemental analysis of biochar. Communications in Soil Science and Plant Analvsis 43 (7): 1042-1052 https://doi.org/10.1080/00103624.2012.656167

12. Fan H. F., Du C. X., Guo S. R. 2012. Effect of nitric oxide on proline metabolism in cucumber seedlings under salinity stress. Journal of the American Society for Horticultural Science, 137 (3): 127-133.

13. Fatma M., Masood A., Per T. S., Rasheed F., Khan N. A. 2016. Interplay between nitric oxide and sulfur assimilation in salt tolerance in nlants. The Cron Iournal, 4 (3): 153-161. https://doi.org/10.1016/j.cj.2016.01.009

14. Giannopolitis C. N., Ries S. K. 1977. Superoxide dismutases I. Occurrence in higher nlants. Plant Physiology, 59 (2): 309-314. https://doi.org/10.1104/pp.59.2.309

15. Heath R. L., Packer L. 1968. Photoperoxidation in isolated chloroplasts. I. Kinetics and stoichiometry of fatty acid peroxidation. Archives of Biochemistry and Binnhysics. 125 (1): 189-198. https://doi.org/10.1016/0003-9861(68)90654-1

16. Jośko I., Stefaniuk M., Oleszczuk P. 2017. Nanomaterialsplant-soil system: challenges and threats. Nanoscience and Plant-Soil Systems o 511-529 https://doi.org/10.1007/978-3-319-46835-8

17. Larue C'., Laurette J., Herlin-Boime N., Khodja H., Fayard B., Flank A. M., Brisset F., Carriere M. 2012 (a). Accumulation, translocation and impact of $\mathrm{TiO}_{2}$ nanoparticles in wheat (Triticum aestivum spp.): influence of diameter and crystal phase. Science of the Total Fnvironment, 431 (1): 197-208. https://doi.org/10.1016/j.scitotenv.2012.04.073

18. Larue C'., Veronesi G., Hlank A. M., Surble S., Herlin-Boime N., Carrière M. 2012 (b). Comparative uptake and impact of $\mathrm{TiO}$ nanoparticles in wheat and rapeseed. Journal of Toxicologv and Fnvirnnmental Health. Part A. 75 (13-15): 722-734. https://doi.org/10.1080/15287394.2012.689800

19. Lei Z., Mingyu S., Xiao W., Chao L., Chunxiang Q., Liang C., Hao H., Xiaoqing L., Fashui H. 2008. Antioxidant stress is promoted by nano-anatase in spinach chloroplasts under UV-B radiation. Binlogical Trace Flement Research, 121 (1): 69-79. https://doi.org/10.1007/s12011-007-8028-0

20. Li J., Naeem M. S., Wang X., Liu L., Chen C., Ma N., Zhang C. 2015. Nano-TiO is not phytotoxic as revealed by the oilseed rape growth and photosynthetic apparatus ultrastructural resnonse. PI oS ONF, 10 (12): 1-12. https://doi.org/10.1371/journal.pone.0143885

21. Li Q. Y., Niu H. B., Yin J., Wang M. B., Shao H. B., Deng D. Z., Chen X. X., Ren J. P., Li Y. C. 2008. Protective role of exogenous nitric oxide against oxidative-stress induced by salt stress in barley (Hordeum vulgare). Colloids and Surfaces R: Rininterfaces, 65 (2): 220-22.5. https://doi.org/10.1016/j.colsurfb.2008.04.007 
22. Liu S., Dong Y., Xu L., Kong J. 2014. Effects of foliar applications of nitric oxide and salicylic acid on salt-induced changes in photosynthesis and antioxidative metabolism of cotton seedlings. Plant Growth Regulation. 73 (1): 67-78. https://doi.org/10.1007/s10725-013-9868-6

23. Loreto F., Velikova V. 2001. Isoprene produced by leaves protects the photosynthetic apparatus against ozone damage, quenches ozone products, and reduces lipid peroxidation of cellular membranes. Plant Physiology, 127 (4): 1781-1787. https://doi.org/10.1104/pp.010497

24. Martínez-Fernández D., Vítková M., MichálkováZ., Komárek M. 2017. Engineered nanomaterials for phytoremediation of metal/metalloid-contaminated soils: implications for plant physiology. Ansari A. et al. (eds). Phytoremediation n. 369-403

https://doi.org/10.1007/978-3-319-52381-1 14

25. Mingyu S., Fashui H., Chao L., Xiao W., Xiaoqing L., Liang C., Fengqing G., Fan Y., Zhongrui L. 2007. Effects of nano-anatase $\mathrm{TiO}_{2}$ on absorption, distribution of light, and photoreduction activities of chloroplast membrane of spinach. Biological Trace Element Research, 118 (2): 120-130. https://doi.org/10.1007/s12011-007-0006-z

26. Mohammadi H., Esmailpour M., Gheranpaye A. 2016. Effects of $\mathrm{TiO}_{2}$ nanoparticles and water-deficit stress on morpho-physiological characteristics of dragonhead (Dracocephalum moldavica L.) plants. Acta Agriculturae Slovenica, 107 (2): 385-396. https://doi.org/10.14720/aas.2016.107.2.11

27. Mohammadi K., Maali-Amiri R., Abbasi A. 2013. Effect of $\mathrm{TiO}_{2}$ nanoparticles on chickpea response to cold stress. Biological Trace Flement Research 152 (3): 403-410. https://doi.org/10.1007/s12011-013-9631-x

28. Mohammadi K., Maali-Amiri K., Mantri N. 2014. Effect of $\mathrm{TiO}_{2}$ nanoparticles on oxidative damage and antioxidant defense systems in chickpea seedlings during cold stress. Russian Journal of Plant Physiology, 61 (6): 768-775. https://doi.org/10.1134/S1021443714050124

29. Molassiotis A., Tanou G., Diamantidis G. 2010. NO says more than 'YES' to salt tolerance: salt priming and systemic nitric oxide signaling in plants. Plant Signaling and Behavior. 5 (3): 209-212.

https://doi.org/10.4161/psb.5.3.10738

30. Nakano Y., Asada K. 1981. Hydrogen peroxide is scavenged by ascorbate-specific peroxidase in spinach chloroplasts. Plant and Cell Physiology. 22 (5): 867-880. https://doi.org/10.1093/oxfordjournals.pcp.a076232

31. Shan C., Yang 1. 2017. Nitric oxide acts downstream of hydrogen peroxide in the regulation of ascorbate and glutathione metabolism by jasmonic acid in Agropyron cristatum leaves. Biologia Plantarum, 1:1-6. https://doi.org/10.1007/s10535-017-0708-9

32. Singh P., Singh R., Borthakur A., Srivastava P., Srivastava N., Tiwary D., Mishra P. K. 2016. Effect of nanoscale $\mathrm{TiO}_{2}$ activated carbon composite on Solanum lycopersicum (L.) and Vigna radiata (L.) seeds germination. Energy, Ecology and Environment, 1 (3): 131-140. https://doi.org/10.1007/s40974-016-0009-8

33. Song G., Gao Y., Wu H., Hou W., Zhang C., Ma H. 2012. Physiological effect of anatase $\mathrm{TiO}_{2}$ nanoparticles on Lemna minor. Environmental Toxicology and Chemistry, 31 (9): 2147-2152. https://doi.org/10.1002/etc.1933

34. Song U., Jun H., Waldman B., Roh J., Kim Y., Yi J., Lee E. J. 2013. Functional analyses of nanoparticle toxicity: a comparative study of the effects of $\mathrm{TiO}_{2}$ and $\mathrm{Ag}$ on tomatoes (Lycopersicon esculentum). Ecotoxicology and Fnvironmental Safety, 93 (1): 60-67. https://doi.org/10.1016/j.ecoenv.2013.03.033

35. 'lanentzap F. M., Stempel A., Ryser P. 2015. Reliability of leaf relative water content (RWC) measurements after storage: consequences for in sitı measurements. Botany, 93 (9): 535-541. https://doi.org/10.1139/cjb-2015-0065

36. Yamori W., Masumoto C., Fukayama H., Makino A. 2012. Rubisco activase is a key regulator of non-steady-state photosynthesis at any leaf temperature and, to a lesser extent, of steady-state photosynthesis at high temperature. The Plant Journal. 71 (6): 871-880.

https://doi.org/10.1111/j.1365-313X.2012.05041.x

ISSN 1392-3196 / e-ISSN 2335-8947

Zemdirbyste-Agriculture, vol. 105, No. 2 (2018), p. 123-132

DOI $10.13080 /$ z-a.2018.105.016

\title{
Titano nanodioksidas ir azoto oksidas sumažina druskos streso sukeltus miežių daigų augimo, fiziologinių ir fotosintetinių savybių pokyčius
}

\author{
A. Karami, A. Sepehri \\ Bu-Ali Sina universitetas, Iranas
}

\section{Santrauka}

Pastaruoju metu vis labiau domimasi inžinerinių nanodalelių naudojimu žemès ūkio moksle. Atlikti tyrimai parodè, kad nanodalelès augalu augimui turi ir teigiamą, ir neigiama poveikị. Šis tyrimas remiasi prieštaringais rezultatais, gautais atliekant ankstesnius inžinerinių nanodalelių poveikio augalų augimui tyrimus. Eksperimentas buvo atliktas šiltnamyje, siekiant ištirti galima titano nanodioksido (n-TiO $)\left(500,1000\right.$ ir $\left.2000 \mathrm{mg} \mathrm{kg}^{-1}\right)$ ir azoto oksido (100 $\mu \mathrm{M}$ natrio nitriprusido kaip azoto monoksido donoro) poveikị miežių daigų, esančių 30 vystymosi tarpsnyje pagal Zadokso skalę, augimui, fiziologiniams ir fotosintetiniams rodikliams veikiant druskos stresui. Druskos streso paveikti augalai lèčiau augo, sumažejo jų daigų ir šaknų ilgis, chlorofilo kiekis ir žiotelių laidumas (Gs), bet padidèjo prolino ir antioksidacinių fermentų aktyvumas lapų audiniuose. Veikiant druskos stresui n- $\mathrm{TiO}_{2}$ miežių augaluose skatino augimą ir fotonintezę. Natrio nitroprusidas kartu su n- $\mathrm{TiO}_{2}$ neutralizavo žalingą druskos poveiki augalu augimo rodikliams. Panaudojus $100 \mu \mathrm{M}$ natrio nitroprusido nustatytas padidejęs superoksido dismutazès (SOD), katalazès (CAT) ir askorbo peroksidazès (APX) aktyvumas su mažiau malondialdehido. Manoma, kad nanodaleliu ir natrio nitroprusido sukelta druskos tolerancija miežiuose yra susijusi su padidejusiu kai kurių antioksidacinių fermentų aktyvumu. Be to, sumažejusi malondialdehido ir vandenilio peroksido $\left(\mathrm{H}_{2} \mathrm{O}_{2}\right)$ koncentracija miežių daiguose parodè, $\mathrm{kad} \mathrm{n-TiO}$ ir natrio nitroprusido panaudojimas sumažino druskos streso sukeltą oksidacini pažeidimą. Remiantis tyrimo duomenimis galima daryti išvadą, kad n- $\mathrm{TiO}_{2}$, naudojant azoto donorą natrio nitroprusido pavidalu, gali būti perspektyvus būdas siekiant neutralizuoti neigiamą druskos streso poveikį miežių augimui.

Reikšminiai žodžiai: druskos stresas, natrio nitroprusidas, santykinis vandens kiekis. 